\begin{tabular}{c} 
Volume and Issues Obtainable at Center for Sustainability Research and Consultancy \\
Journal of Business and Social Review in Emerging Economies \\
ISSN: 2519-089X (E): 2519-0326 \\
Volume 6: No. 3, 2020 \\
JSRᄃ \\
Journal homepage: www.publishing.globalcsrc.org/jbsee \\
\hline
\end{tabular}

\title{
Social Media and Electoral Campaigns: A Study of 2013 General Elections in Punjab
}

\author{
${ }^{1}$ Abdul Ghani, ${ }^{2}$ Ghulam Shabir, ${ }^{3}$ Qamar Uddin Zia Ghaznavi \\ ${ }^{1}$ Assistant Professor, Department of Mass Communication Minhaj University Lahore, Pakistan \\ ghanimalik83@gmail.com \\ Professor, Faculty of Media and Communication Studies (FMCS), University of Central Punjab, Lahore Pakistan \\ ghulam.shabir@ucp.edu.pk \\ ${ }^{2 \& 3}$ Assistant Professor, Beacon House National University, Lahore Pakistan, dr.ghaznavi@gmail.com
}

\section{ARTICLE DETAILS \\ History \\ Revised format: August 2020 \\ Available Online: September 2020}

\section{Keywords \\ Social Media, Elections, Voting \\ Behavior, Punjab}

\section{JEL Classification}

MO, M1

\begin{abstract}
Social Media sites such as Facebook, YouTube, WhatsApp, IMO, Twitter and Viber have become famous social interaction forums among all age groups in Pakistan. Social media websites remained the most common platform for the exchange of political ideas and political awareness, consequently influencing political mobilization and bringing change in the political setup of Punjab. This study evaluates the impact of social media on molding the behaviors of voters during the general elections in 2013. The aim was to quantify how social media websites affected political mobilization and altered the Pakistani political setup. The findings are based on a survey conducted amongst the population of Punjab belonging to different age groups, gender, profession, qualification, and localities. Significant correlations were found among different variables i.e. gender, age, profession and locality of the participants. This paper suggests that social media has affected the young population most in Pakistan and helped alter the politicalbehavior of voters.
\end{abstract}

\section{OPEN ACCESS}

(C) 2020 Center for Sustainability Research and Consultancy Pakistan under a Creative Commons Attribution-NonCommercial-ShareAlike 4.0

Corresponding author's email address: ghulam.shabir@ucp.edu.pk

Recommended citation: Ghani, A., Shabir, G. \& Ghaznavi, Q. U. Z. (2020). Social Media and Electoral Campaigns: A Study of 2013 General Elections in Punjab. Journal of Business and Social Review in Emerging Economies, 6(3), 975-982

\section{Introduction}

The advent of internet and technology has exposed majority of the global population to different interactive platforms on which different kinds of information is exchanged which might significantly have effect upon human behavior, decision and judgment (Kurfi, 2015). Social media are new information network which uses a form of communication utilizing interactive and user produced content through which interpersonal relationships are created. The Social Media is not used for casual purpose only; rather it is now used for more important purposes like news sharing, propaganda setting, social and political campaigns etc. Social media is changing the trends of the usage of media. People are 
gradually shifting from Traditional and Mass Media towards Social Media. This shift of power and interest of users in New Media Technology has introduced Social Networking Sites as big industries. The Activists, Political Parties are now using Social Media for their Campaigns. The use of Social Media by the protestors during Arabs Spring is also an example of political use of social media. With less penetration as compared to the developed countries, social media is becoming a strong tool for politics and campaigns. During the 2010 Flood, General Elections of 2013 and during Military Operation in North Waziristan, the social media was and is being used for the promotion, propaganda, defamation of the opponents, and for fund raising. The users, in Pakistan are also participating in this whole process through their feedback, likes, comments, and sharing. In this research, the researcher has focused on the use of Social Media in Pakistan, specifically for political campaigns in Punjab.

The role of media in formulating public opinion is well recognized. Media campaigns to persuade voters in a party's favor on the election eve have also been well established. However in different political cultures and contexts, the effects of media campaigns on voting behavior remain different. This study aims to investigate the effect of social media campaign of the major political parties of Pakistan on voting behavior, taking the general elections of 2013 in Punjab as a case study. This empirical study would add an original scholarly contribution to the relevant field. In the general elections of 2013, Pakistan Muslim League (N), Pakistan Tehreek-e-Insaf, and Pakistan People's Party emerged as three leading political parties in this particular region. Hence, this study would compare the media campaigns of these parties.

These three parties have taken part in various elections of Punjab previously, wherein PML (N) and PPP emerged as two largest parties in several elections of the past. However, in the general elections of 2013 the emergence of PTI as a notable player, on provincial as well as the National Assembly seats from Punjab, is a new development. Evidence suggests that PTI and other leading parties paid special attention to their media campaigns for the general elections in order to attract voters from Punjab. This makes the present research important and relevant. This study tends to explore to what extent media campaigns of these parties had a role in guiding voting behavior? In this regard Joseph Pulitzer, a former American mass communication writer and media man said that "Media is both, a daily teacher as well as a daily Tribune". The study will emphasize on the effect of media campaigns on the patterns of electoral support for the respective parties.

\subsection{Social Media and Electoral Campaigns}

There is an emerging agreement among scholars that campaigns matter in elections based on the evidence that the public respond to campaign events (Gibson, 2006). Social media is very useful for election campaigns. It has been argued that the overall results of elections can be influenced by the magnitude of the campaigns (McClurg \& Thomas, 2009). The evidance suggests that a strong and practical online election campaign along with the other traditional media can influence the voting preferences of people (Wasswa, 2013). With reference to the Pakistani case, it has been asserted that in light of election campaigns the social media is taking shape in Pakistan where political candidates are using Facebook and Twitter as election campaign tools along with traditional media to engage their supporters. Now different political parties are using social media for political slogans, comments and criticism (Usman, et al, 2013).

Several studies have been conducted on the use of social media during revolutionary period, crises, elections and referendums. The scholars found the effect that authenticity had on electoral social media campaigns. They found that authenticity was a popular 'buzzword' in electoral politics (Grow \& Janelle, 2013). The study enhanced the existing definitions of authenticity and explained the way authenticity could be demonstrated by electoral candidates in social media campaigns.

Another group of scholars have examined the role of social media in political communication and claimed that the activities of collection, monitoring, visualizing, analyzing and summarizing the politically relevant information from social media has been subsumed under 'social media analytics' (Stieglitz \& Linh, 2013).

Social media are new information network and information technology using a form of communication utilizing interactive and user produced content, and interpersonal relationships are created and maintained. The emergence of the internet as the new mass medium of the $21^{\text {st }}$ century now changes the mass media substantially. Information can 
be distributed at high speed, low cost, and broad scope and as a result there is egalitarian access to the production and the consumption of news (Prat \& Strömberg, 2011) .

Okoro and Nwafor tested social media usage in political participation during 2011 general elections in Nigeria. They found that Nigeria had used social media in political participation for the first time. ${ }^{8}$ According to the findings, social media was used by several participants to make important input in political discourse; however others used them for attacking opponents, spreading false rumors, hate and inciting messages which contributed in violence that was witnessed before, during and after the elections in the country. Their study suggested review of various media laws that could monitor the use of different social media platforms (Okoro \& Kenneth, 2013)

Political parties are actively using social media platforms such as weblogs and social networking sites to disseminate political information to the voting public (Herman, 2012; Herman \& Kim, 2014).

The effect of internet was tested on different aspects of voting behavior and found that internet access had negative effects on voter turnout. They found that the internet crowded other forms of media that contained much better information. They took the example of newspapers as 'other' media and found that these newspapers are affected by the internet (Falck et al., 2014).

Social media brings politicians and parties closer to their potential voters through personal communication (social media in politics. blogspot.com). Political campaigns can create a unique electoral context that affects voter behavior especially in terms of their vote choice (Bratu, 2013).

Similarly, the effect internet had been tested on different aspects of voting behavior and found that internet access had negative effects on voter turnout. They found that the internet crowded other forms of media that contained much better information. They took the example of newspapers as 'other' media and found that these newspapers are affected by the internet (Okoro \& Tsegyu , 2017).

\subsection{General Elections (2013) in Pakistan}

On 11 May, 2013 General Elections were held in Pakistan. The major contesting parties in Elections were PML (N) and Pakistan People's Party but at this time a new factor Pakistan Tehreek e Insaf was present with mighty force. These three parties have taken part in various elections of Punjab previously, with PML (N) and PPP emerging as two largest parties in several elections of the past. However, in the general elections of 2013 PTI emerged as a competing player, on provincial as well as the National Assembly seats. PML (N), PTI and PPP paid special attention to their media campaigns for the general elections in order to attract voters from around Punjab. According to the ranking of Pakistani politicians issued by social media websites Facebook and Twitter (Nov, 14, 2013) the leader of Pakistan Tehreek e Insaf (PTI) Imran Khan stood on the top with the most followers on Facebook and Twitter during Elections 2013. Pakistan Muslim League Nawaz PML (N) Shahbaz Sharif was on second position, Marvi Memon was at number 3 and Maryam Nawaz Sharif was at number 4 on social media (Facebook and Twitter) ranking (www.currentaffairspk.com, retrieval date March, 25, 2016).

\section{Methodology}

The argument of this paper is based on the quantitative analysis of the findings of survey research conducted for the doctoral thesis of the author. The target population for this study was the registered voters of Punjab that uses social media. The survey was conducted during March-July 2016 in different areas of Punjab to investigate the role of social media in the voting behavior. The sample was stratified by age, gender, qualification, profession, and the territory. The sample was designed in a way to make it more representative of the Punjabi electorate. The voters of different age groups based in various regions of the Punjab i.e. Central Punjab, North Punjab, and South Punjab were consulted. A total of 891 interviews were conducted from all over the Punjab, in Urdu and English. In addition to face-to-face interviews, sizeable voters were interviewed electronically. As an enormous information was gathered, the analysis of the data was conducted through the SPSS. The questionnaire was composed of two sections. The first section was reserved to gather the demographic information of the respondents such as age group, gender, qualification, profession, and the region. The second section of the questionnaire was comprising of a set of close-ended questions to get the 
response of respondents concerning the role of social media in the voting behavior of Punjab.

Owing to its relatively narrower scope in comparison to the doctoral thesis, this paper does not cover the findings of the whole questionnaire, but it limited to the ten most relevant questions to the study. The questions interrogate how often the people use social media, and to what extent the electoral campaigns launched by political parties through social media influence the voting behavior. The questionnaire also gathers opinion of the respondents about the usage of social media, the level of interest and its impact on the voting behavior of the respondents. It also gauges the frequency of discussion surrounding determinants of voting behavior on social media and distribution of the information retrieved from social media with family and friends. Then, it examines whether social media is more imperative than the electronic media and if the General Elections 2013 could be considered as the elections of social media. Finally, it evaluates usage of social media for electoral campaign by major parties of Punjab.

\subsection{Election Campaigns, Voting Behavior, and the Social Media: Survey of Voters opinion}

This section presents findings of the survey that was aimed to examine the relevance and usage of social media in the political campaigns during elections. The survey illustrates useful insights to comprehend the growing shift in the political and electoral strategies as a result of the development in the fields of media and technology. The results of selected questions asked by the respondents are discussed in this section. The Table-1 summarizes the findings of the first two questions.

\section{Table-1: Social Media and Election Campaigns-I}

\begin{tabular}{|c|c|c|c|c|c|}
\hline \multicolumn{3}{|c|}{ How often you use Social Media? } & \multicolumn{3}{c|}{$\begin{array}{r}\text { To what extent Electoral Campaigns on Social } \\
\text { Media influence the voting behavior? }\end{array}$} \\
\hline Options & Frequency & Percentage & Options & Frequency & Percentage \\
\hline Very Often & 350 & 39.3 & To great extent & 212 & 23.8 \\
\hline Often & 327 & 36.7 & To some extent & 439 & 49.3 \\
\hline Sometimes & 156 & 17.5 & Neutral & 104 & 11.7 \\
\hline Rarely & 48 & 5.4 & To little extent & 98 & 11.0 \\
\hline Never & 10 & 1.1 & Not at all & 38 & 4.3 \\
\hline
\end{tabular}

(Source Ghani, 2018)

When it was asked by the respondents, how often you use social media? Almost three-fourth of the respondents confirmed that they often use social media. The rest of the respondents also used the social media but not frequently. This finding verified that relevance of sample as the target population for this study was the electorate that is familiar with the social media. In response to another question that to what extent electoral campaigns on social media influence the voting behavior, almost one-fourth of the interviewee opined that it influences greatly. Another, almost fifty-percent respondents agreed that social media effects the voting behavior but slightly. The rest of the respondents (around one-fourth of the total) remained neutral and suggested that the impact is negligible. The findings of these questions were verified by the subsequent questions that interrogated the strength of social media. 
Table-2: Social Media and Election Campaigns-II

\begin{tabular}{|l|c|c|c|c|c|c|}
\hline Options & \multicolumn{3}{|l|}{$\begin{array}{l}\text { Do you agree that } \\
\text { Social Media should be } \\
\text { used for Election }\end{array}$} & $\begin{array}{l}\text { Do you agree that Social } \\
\text { Campaigns? }\end{array}$ & $\begin{array}{l}\text { Media plays more vital } \\
\text { role than the electronic } \\
\text { media for Election } \\
\text { Campaigns? }\end{array}$ & $\begin{array}{l}\text { Do you agree that } \\
\text { General Elections 2013 } \\
\text { were the elections of } \\
\text { Social Media? }\end{array}$ \\
\hline & Frequency & Percentage & Frequency & Percentage & Frequency & Percentage \\
\hline $\begin{array}{l}\text { Strongly } \\
\text { agree }\end{array}$ & 197 & 22.1 & 194 & 21.8 & 129 & 14.5 \\
\hline Agree & 442 & 49.6 & 390 & 43.8 & 338 & 37.9 \\
\hline Neutral & 143 & 16.0 & 165 & 18.5 & 171 & 19.2 \\
\hline Disagree & 76 & 8.5 & 107 & 12.0 & 191 & 21.4 \\
\hline $\begin{array}{l}\text { Strongly } \\
\text { disagree }\end{array}$ & 33 & 3.7 & 35 & 3.9 & 62 & 7.0 \\
\hline
\end{tabular}

(Source Ghani, 2018)

The findings presented in Table- 2 demonstrate the relevance of social media for the electoral campaigns more strongly. The survey put question to the respondents that whether social media should be used for election campaigns. More than seventy-percent of the respondents acknowledged the relevance of social media for election campaigns. While sixteen-percent remained neutral, around twelve-percent did not approve the usage of social media in electoral campaigns. The survey asked the respondents whether the social media plays more vital role than the electronic or print media for election campaigns. The response of this question revealed that almost two-third of the total respondents agreed that social media is more vital than electronic and print media to attract the voters. Then, the survey asked the respondents whether it is appropriate to argue that the General Elections 2013 were the elections of social media. In response, more than half of the respondents agreed to this assertion. However, a considerable number of respondents did not agree with this argument. Once it approved by the respondents that social media plays vital role in the election campaigning, the analysis now turns to assess how much voters are keen to learn the political contents dispensed by the political parties through social media and how this content can influence the voters' choice. The Table-3 presents summary of the results in this regard.

Table-3: Political Contents of the Social Media and Voting Behavior

\begin{tabular}{|c|c|c|c|c|c|c|c|c|c|c|}
\hline \multirow[b]{2}{*}{ 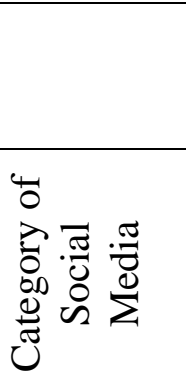 } & \multicolumn{5}{|c|}{$\begin{array}{l}\text { How much interest do you take in the } \\
\text { political contents of the social media? }\end{array}$} & \multicolumn{5}{|c|}{$\begin{array}{l}\text { How much the information acquired from } \\
\text { the social media influenced your voting } \\
\text { decision? }\end{array}$} \\
\hline & $\sum_{\sum_{0}^{0}}^{\overline{0}}$ & 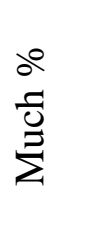 & 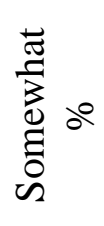 & 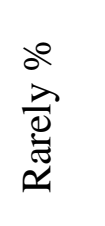 & $\begin{array}{l}0 \\
0 \\
\bar{\sigma} \\
\tilde{\sigma} \\
0 \\
z\end{array}$ & 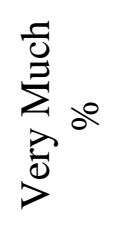 & $\begin{array}{l}0 \\
\overline{0} \\
\sum_{\Sigma}^{2}\end{array}$ & 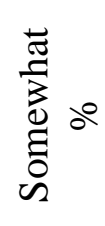 & 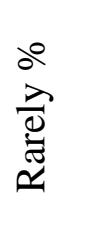 & $\begin{array}{l}0^{0} \\
\bar{\pi} \\
\tilde{\sigma} \\
\tilde{0} \\
z\end{array}$ \\
\hline Facebook & 38.3 & 24.1 & 16.9 & 13.4 & 7.3 & 41.3 & 25.0 & 12.5 & 7.1 & 14.1 \\
\hline WhatsApp & 24.8 & 22.6 & 18.5 & 13.1 & 21.0 & 15.4 & 19.1 & 19.5 & 15.8 & 30.2 \\
\hline YouTube & 25.0 & 24.8 & 18.3 & 13.9 & 18.0 & 18.7 & 18. & 20.2 & 15.2 & 27.3 \\
\hline Twitter & 15.6 & 19.8 & 15.7 & 16.7 & 32.2 & 20.1 & 22 & 19.1 & 10.5 & 27.7 \\
\hline LinkedIn & 8.1 & 12.7 & 17.3 & 15.3 & 46.7 & 8.5 & 14.4 & 24.0 & 14.3 & 38.8 \\
\hline Imo & 8.2 & 9.9 & 16.5 & 17.1 & 48.9 & 5.6 & 12.1 & 18.0 & 17.3 & 47.0 \\
\hline Viber & 15.3 & 16.5 & 12.6 & 17.6 & 38.0 & 4.5 & 11.2 & 18.1 & 18.5 & 47.7 \\
\hline Others & 11.1 & 13.4 & 18.9 & 14.1 & 42.5 & 6.5 & 13.0 & 18.1 & 18.5 & 43.9 \\
\hline
\end{tabular}

(Source Ghani, 2018)

When it was asked by the respondents how much interest do you take in the political contents available on certain categories of social media. The results revealed that Facebook is the most popular device used for electoral campaign 
on social media. Then, the WhatsApp and YouTube were used more frequently for promotion of political contents on social media. In response to the question that how much usage of social media influenced your voting decision, Facebook Twitter, and YouTube appeared as the most influential devices. Almost two-third of the respondents confirmed that the political content shared on Facebook contributed to their voting decisions significantly. Equally, almost forty-two percent of the respondents agreed that political contents shared through Twitter influenced their voting behavior greatly. In addition, nearly forty percent of the interviewee stated that the political contents shared through WhatsApp contributed to their voting decisions. The following section unveils the frequency of social media debates related to the 2013 General Elections and how these debates were stretched to the family and social meetings. The Table-4 demonstrates some very useful information to grasp the spectrum of such debates.

Table-4: Debating Elections and Social Media

\begin{tabular}{|c|c|c|c|c|c|c|c|c|c|c|c|}
\hline \multicolumn{6}{|c|}{$\begin{array}{l}\text { How often the factors involved in voting } \\
\text { behavior were discussed on social media in the } \\
\text { general elections 2013? }\end{array}$} & \multicolumn{6}{|c|}{$\begin{array}{l}\text { To what extent you shared political information } \\
\text { acquired from social media with others? }\end{array}$} \\
\hline & $\begin{array}{l}b^{0} \\
\text { ẽ } \\
\stackrel{0}{0} \\
\stackrel{2}{0} \\
>\end{array}$ & $\underbrace{\frac{2}{2}}_{0}$ & 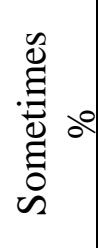 & 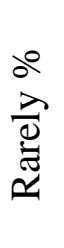 & $\begin{array}{l}D^{0} \\
\dot{0} \\
\dot{0} \\
z\end{array}$ & & 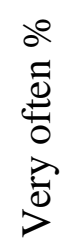 & $\underbrace{\infty}_{0}$ & 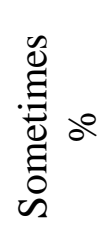 & $\frac{\lambda^{2}}{d=}$ & $\begin{array}{l}\theta^{0} \\
\overline{0} \\
\dot{\partial} \\
\bar{z}\end{array}$ \\
\hline Ethnicity & $\begin{array}{c}22 . \\
2\end{array}$ & $\begin{array}{c}33 . \\
7\end{array}$ & $\begin{array}{c}21 . \\
0\end{array}$ & $\begin{array}{c}13 . \\
6\end{array}$ & 9.5 & $\begin{array}{l}\text { Friends/Collea } \\
\text { gues }\end{array}$ & $\begin{array}{c}35 . \\
7\end{array}$ & $\begin{array}{r}28 \\
1 \\
\end{array}$ & 15.6 & $\begin{array}{c}11 . \\
2\end{array}$ & 9.4 \\
\hline Beradrisim & $\begin{array}{c}21 . \\
9\end{array}$ & $\begin{array}{c}34 . \\
2\end{array}$ & $\begin{array}{c}23 . \\
1\end{array}$ & $\begin{array}{c}11 . \\
7\end{array}$ & 9.1 & Family & $\begin{array}{r}25 . \\
1\end{array}$ & $\begin{array}{r}29 \\
7\end{array}$ & 21.9 & $\begin{array}{c}16 . \\
3\end{array}$ & 13.0 \\
\hline Personality & $\begin{array}{c}30 . \\
1\end{array}$ & $\begin{array}{c}28 . \\
2\end{array}$ & $\begin{array}{c}21 . \\
4\end{array}$ & $\begin{array}{c}12 . \\
2\end{array}$ & 8.1 & Peer groups & $\begin{array}{c}19 \\
3\end{array}$ & $\begin{array}{r}20 \\
4\end{array}$ & 24.4 & $\begin{array}{c}15 . \\
9\end{array}$ & 20.0 \\
\hline $\begin{array}{c}\text { Party } \\
\text { affiliation }\end{array}$ & $\begin{array}{c}28 . \\
2\end{array}$ & $\begin{array}{c}32 . \\
7\end{array}$ & $\begin{array}{c}20 . \\
7\end{array}$ & $\begin{array}{c}10 . \\
4\end{array}$ & 8.1 & Neighbors & $\begin{array}{c}11 . \\
9\end{array}$ & $\begin{array}{r}15 \\
0\end{array}$ & 22.0 & $\begin{array}{c}22 . \\
7\end{array}$ & 28.4 \\
\hline Others & $\begin{array}{c}24 . \\
8\end{array}$ & $\begin{array}{c}28 . \\
3\end{array}$ & $\begin{array}{c}22 . \\
8 \\
\end{array}$ & $\begin{array}{c}14 . \\
1\end{array}$ & 9.9 & Others & $\begin{array}{c}11 . \\
2\end{array}$ & $\begin{array}{c}12 \\
2\end{array}$ & 24.0 & $\begin{array}{c}23 . \\
5\end{array}$ & 29.1 \\
\hline
\end{tabular}

(Source Ghani, 2018)

The findings of this survey show that issues related to the electoral politics and voting behavior get massive coverage by the social media. The respondents revealed that they were engaged in debates concerning the various determinates of voting behavior. More than half of the total respondents agreed that they often discussed the role of ethnicity, Beradrisim, candidate's personality, and the party affiliation in voting behavior of Punjab. Most of the respondents agreed that they discussed the content of political campaign on social media with the family and friends. They also discussed the information retrieved from social media with peer groups, neighbors etc. Now, the paper presents the analysis of social media usage by the three major contenders in the province of Punjab. The results summarized in the Table- 5 suggests that the parties profoundly relied on the social media to advertise their agendas and programs. They transmitted party slogans and party songs on the social media to mesmerize and appeal the masses. The party candidates also used this platform to convince the voters at local level to strengthen their electoral support at constituency level.

Table-5: Electoral Campaigns and Social Media: 2013 General Elections

How much information related to political campaigns you acquired from social media for various parties?

\begin{tabular}{|c|c|c|c|c|c|c|c|c|c|c|c|c|c|c|c|}
\hline & \multicolumn{5}{|c|}{ Pakistan Muslim League-N } & \multicolumn{5}{|c|}{ Pakistan People's Party } & \multicolumn{5}{|c|}{ Pakistan Tehreek e Insaf } \\
\hline & $\stackrel{\substack{0 \\
\frac{0}{0}}}{\frac{0}{2}}$ & $\begin{array}{l}0^{0} \\
\frac{1}{0} \\
\sum^{3}\end{array}$ & 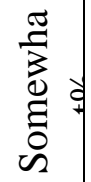 & 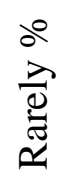 & $\begin{array}{l}\bar{\Xi} \\
\tilde{\Xi} \\
\tilde{0} \\
z\end{array}$ & $>^{2}$ & $\begin{array}{l}\theta^{e} \\
\frac{0}{0} \\
\stackrel{2}{\Sigma}\end{array}$ & 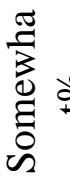 & 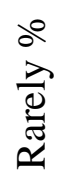 & 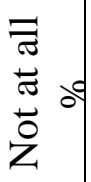 & 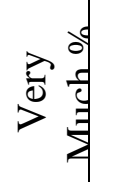 & $\begin{array}{l}\delta^{2} \\
\frac{5}{0} \\
\stackrel{3}{2}\end{array}$ & $\begin{array}{l}\frac{\pi}{2} \\
3 \\
0 \\
0 \\
0 \\
0\end{array}$ & 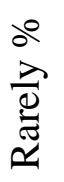 & 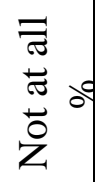 \\
\hline
\end{tabular}




\begin{tabular}{|c|c|c|c|c|c|c|c|c|c|c|c|c|c|c|c|}
\hline $\begin{array}{l}\text { Party } \\
\text { leader }\end{array}$ & 29.2 & $\begin{array}{c}33 . \\
2\end{array}$ & $\begin{array}{c}16 . \\
0\end{array}$ & $\begin{array}{c}11 . \\
1\end{array}$ & $\begin{array}{c}10 . \\
4\end{array}$ & $\begin{array}{c}29 . \\
9\end{array}$ & $\begin{array}{c}25 . \\
5\end{array}$ & $\begin{array}{c}13 . \\
4\end{array}$ & $\begin{array}{c}16 . \\
4\end{array}$ & $\begin{array}{c}14 . \\
9\end{array}$ & $\begin{array}{c}24 . \\
9\end{array}$ & $\begin{array}{c}16 . \\
0\end{array}$ & $\begin{array}{c}15 . \\
4\end{array}$ & $\begin{array}{c}21 . \\
4\end{array}$ & $\begin{array}{c}22 . \\
2\end{array}$ \\
\hline $\begin{array}{l}\text { Manifes } \\
\text { to }\end{array}$ & 17.6 & $\begin{array}{c}19 . \\
8\end{array}$ & $\begin{array}{c}20 . \\
4\end{array}$ & $\begin{array}{c}24 . \\
5\end{array}$ & $\begin{array}{c}17 . \\
7\end{array}$ & $\begin{array}{c}28 . \\
5\end{array}$ & $\begin{array}{c}26 . \\
6\end{array}$ & $\begin{array}{c}16 . \\
2\end{array}$ & $\begin{array}{c}16 . \\
4\end{array}$ & $\begin{array}{c}12 . \\
3\end{array}$ & $\begin{array}{c}21 . \\
4\end{array}$ & $\begin{array}{c}18 . \\
5\end{array}$ & $\begin{array}{c}18 . \\
1\end{array}$ & $\begin{array}{c}18 . \\
4\end{array}$ & $\begin{array}{c}23 . \\
5\end{array}$ \\
\hline $\begin{array}{l}\text { Party } \\
\text { Slogans }\end{array}$ & 24.2 & $\begin{array}{c}21 . \\
2\end{array}$ & $\begin{array}{c}21 . \\
5\end{array}$ & $\begin{array}{c}16 . \\
4\end{array}$ & $\begin{array}{c}16 . \\
6\end{array}$ & $\begin{array}{c}33 . \\
8\end{array}$ & $\begin{array}{c}26 . \\
0\end{array}$ & $\begin{array}{c}14 . \\
6\end{array}$ & $\begin{array}{c}12 . \\
5\end{array}$ & $\begin{array}{c}13 . \\
1\end{array}$ & $\begin{array}{c}21 . \\
7\end{array}$ & $\begin{array}{c}19 . \\
0\end{array}$ & $\begin{array}{c}17 . \\
1\end{array}$ & $\begin{array}{c}18 . \\
9\end{array}$ & $\begin{array}{c}23 . \\
2\end{array}$ \\
\hline $\begin{array}{l}\text { Party } \\
\text { Songs }\end{array}$ & 21.5 & $\begin{array}{c}21 . \\
2\end{array}$ & $\begin{array}{c}20 . \\
2\end{array}$ & $\begin{array}{c}17 . \\
4\end{array}$ & $\begin{array}{c}19 . \\
6\end{array}$ & $\begin{array}{c}15 . \\
5\end{array}$ & $\begin{array}{c}21 . \\
4\end{array}$ & $\begin{array}{c}15 . \\
8\end{array}$ & $\begin{array}{c}22 . \\
4\end{array}$ & $\begin{array}{c}24 . \\
8\end{array}$ & $\begin{array}{c}20 . \\
0\end{array}$ & $\begin{array}{c}13 . \\
0\end{array}$ & $\begin{array}{c}18 . \\
9\end{array}$ & $\begin{array}{c}20 . \\
3\end{array}$ & $\begin{array}{c}27 . \\
8\end{array}$ \\
\hline $\begin{array}{l}\text { Candida } \\
\text { te }\end{array}$ & 23.9 & $\begin{array}{c}23 . \\
9\end{array}$ & $\begin{array}{c}21 . \\
9\end{array}$ & $\begin{array}{c}17 . \\
4\end{array}$ & $\begin{array}{c}13 . \\
2\end{array}$ & $\begin{array}{c}31 . \\
0\end{array}$ & $\begin{array}{c}26 . \\
7\end{array}$ & $\begin{array}{c}16 . \\
6\end{array}$ & $\begin{array}{c}13 . \\
1\end{array}$ & $\begin{array}{c}12 . \\
9\end{array}$ & $\begin{array}{c}20 . \\
3\end{array}$ & $\begin{array}{c}15 . \\
9\end{array}$ & $\begin{array}{c}16 . \\
0\end{array}$ & $\begin{array}{c}20 . \\
5\end{array}$ & $\begin{array}{c}27 . \\
0\end{array}$ \\
\hline Others & 33.0 & $\begin{array}{c}29 . \\
4\end{array}$ & $\begin{array}{c}12 . \\
9\end{array}$ & $\begin{array}{c}10 . \\
0\end{array}$ & $\begin{array}{c}14 . \\
7\end{array}$ & $\begin{array}{c}15 . \\
5\end{array}$ & $\begin{array}{c}11 . \\
1\end{array}$ & $\begin{array}{c}16 . \\
3\end{array}$ & $\begin{array}{c}25 . \\
5\end{array}$ & $\begin{array}{c}31 . \\
6\end{array}$ & $\begin{array}{c}15 . \\
9\end{array}$ & $\begin{array}{c}13 . \\
4\end{array}$ & $\begin{array}{c}20 . \\
9\end{array}$ & $\begin{array}{c}22 . \\
2\end{array}$ & $\begin{array}{c}27 . \\
6\end{array}$ \\
\hline
\end{tabular}

(Source Ghani, 2018)

It was also interesting to explore the extent to which the three major parties of Punjab, PML-N, PTI, and PPP used social media for election campaigns during the 2013 General Elections in Punjab. The information related to party leaders and party manifestos was posted by the respective political parties on the social media. The results show that the respondents found much information about party leadership on social media. A vast majority of respondents (sixty-two percent) stated that they found much information about the Pakistan Muslim League-N leadership. Nonetheless, a sizeable number of respondents gather information about the leadership of Pakistan people's Party (forty-six percent) and Pakistan Tehreek-e-Insaf (forty percent). Political parties present their programs and publish manifestos to attract the electorate and share the party policy positions on certain issues during the elections. Now, the parties use social media to publicize their programs. During the 2013 General Elections, according to findings of the survey, the major parties sufficiently disseminated the party manifestos on social media. A considerable number of respondents argued that they found much information about the party manifestos of PML-N (thirty-seven percent), PPP (forty-two percent), and PTI (forty percent). The major parties of Punjab widely used the party slogans and party songs to attract the voters. PPP (sixty percent) remained ahead and proliferated the party slogans more vigorously than the PML-N (forty-five percent) and PTI (forty percent). However, PML-N (forty-three percent) dispensed more party songs on social media than the PPP (thirty-seven percent) and PTI (thirty-three percent). The party candidates also launched election campaigns on social media to convince the voters of their constituencies for support. In this regard, the candidates of PPP (fifty-eight percent) appeared more vigilant and alert to interact with the masses through modern tools of election campaigns than the candidates of PML-N (forty-eight percent) and PTI (thirty-six percent). Overall, the reliance of major parties on social media for election campaign suggests the shift in the election campaign strategies of political parties and reflects the strength and relevance of social media in the political and social events.

\section{Conclusion}

This paper investigates the role of social media in the electoral campaigns of 2013 General Elections in the province of Punjab, Pakistan. The argument is based on the quantitative analysis of a survey of opinion of the Punjabi electorate. The survey involved a close-ended questionnaire to gather the opinion by a carefully designed representative sample. The findings of the survey seem to suggest that the social media has accomplished great importance in the fields of political campaigning and electoral strategies. The growing relevance of social media in the global world has serious consequences for the electoral fate of political parties. The findings revealed the immense usage of social media for electoral and political purposes. The survey suggests that Facebook, WhatsApp, YouTube, and Twitter are used commonly for dissemination of party policy positions, party manifestos, and political slogans. The social media is often used for elevation of the image of the Party leadership and equally for stressing the faults of the rival parties. The majority of the respondents that use social media confirmed that they often access the political contents available on social media and are seriously influenced by the messages conveyed through these contents. They believe that the debates concerning the voter choice preferences are useful and they stretch these debates to the family and social circles. In this way, it can be argued that the social media not only contributes to the voting choice decision of the social media users but also to the non-users. It is worth mentioning that the plentiful respondents argue that social media is more effective than the electronic media for electoral campaigns. They even regarded the 2013 General Elations as the elections of social media. The major parties of Punjab, PML-N, PPP, and PTI recognized the 
importance of social media and launched their social media campaigns very effectively in the 2013 General Elations. The findings of the survey suggest that PML-N and PPP focused more seriously on the usage of social media than the PTI. However, PPP could not sustain its electoral support in Punjab and PTI emerged as second largest party of Punjab in 2013 elections. Therefore, it can be argued that although social media is an essential ingredient of the modern electoral strategies, it cannot guarantee the electoral success. The paper argue that multiple factors determine the electoral fate of the political parties. However, the effective use of social media for electoral campaigning enhances the prospects of success.

\section{References}

Bratu, S. (2013). The impact of political advertising on individual vote choice. Geopolitics, History, and International Relations(1), 124-129.

Falck, Oliver, Robert, Gold, and Stephan Heblich. (2014). E-Lections: Voting Behavior and the Internet. The American Economic Review.

Gibson, Rachel K \& Ian, McAllister. (2006). Does Cyber-Campaigning Win Votes? Online Communication in the 2004 Australian Election. Journal of Elections, Public Opinion and Parties.

Grow, Gabrielle \& Janelle Ward.(2013). The Role of Authenticity in Electoral Social Media Campaigns. First Monday.

Herman, B. D. (2012). Taking the copyfight online: Comparing the copyright debate in congressional hearings, in newspapers, and on the web. Journal of Computer-Mediated Communication, 17(3), 354-368.

Kurfi, Dr Mainasara Yakubu. (2015). Department of Mass Communication Faculty of Social and Management Sciences Bayero University, Kano.

McClurg, Scott D \& Thomas, M Holbrook. (2009). Living in a Battleground: Presidential Campaigns and Fundamental Predictors of Vote Choice. Political Research Quarterly.

Okoro, Nnanyelugo \& Kenneth, Adibe Nwafor. (2013). Social Media and Political Participation in Nigeria During the 2011 General Elections: The Lapses and the Lessons." Global Journal of Arts Humanities and Social Sciences.

Okoro, Nnanyelugo \& Tsegyu Santas. (2017). An Appraisal of the Utilisation of Social Media for Political Communication in the 2011 Nigerian Presidential Election. African Research Review.

Prat, A., \& Strömberg, D. (2011). The political economy of mass media.

Stieglitz, Stefan \& Linh, Dang-Xuan.(2013). Social Media and Political Communication: A Social Media Analytics Framework. Social Network Analysis and Mining.

Usman, Ahmed, Riffat Munawar, and Aaisha Amjad. (2013). Determinants of Effective Electoral Campaign. South Asian Studies.

Wasswa, Humphrey Wachuli. (2013). The Role of Social Media in the 2013 Presidential Election Campaigns in Kenya. Research project submitted to the School of Journalism and Mass Communication, University of Nairobi, Kenya. 